\title{
Sakharov - a wind of change?
}

\section{- Sakharov's internal exile ends at last - Campaign on human rights continues - Plans for a return to science}

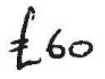

London

DR Andrei Dmitrievich Sakharov, 'father of the Soviet hydrogen bomb', Nobel Peace Prize winner and doyen of the Soviet human rights movement, is alive, reasonably well, extremely vocal, and once more living in Moscow with his wife, Yelena Bonner. His 'administrative exile', announced on 22 January 1980, has been rescinded after almost seven years, and his wife's sentence quashed so that they could return, together, to Moscow. The surprise announcement, coming at the end of a year that also saw the depar-

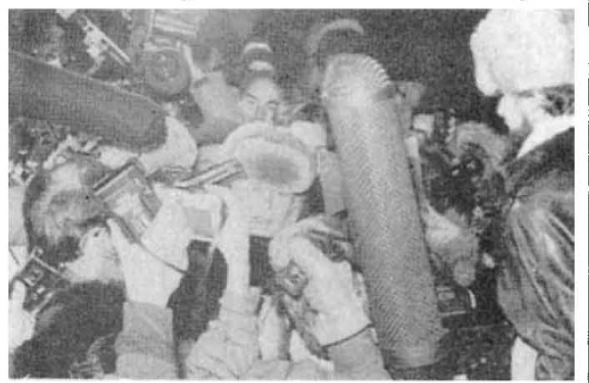

Sakharov has been the centre of much attention from the Western media.

ture from the Soviet Union of such notable human rights campaigners as Anatolii (now Nathan) Shcharanskii and Yurii Orlov, is seen as a major signal of a new Soviet attitude on human rights issues.

These events, however, have to be viewed against a wider background. So far, those who have benefited most have been the big names among the Soviet scientific dissidents and refusniks, for whom major campaigns have been launched. During the past seven years, Sakharov's exile, in particular, has on several occasions been a cause of embarrassment to Soviet scientists and diplomats in their encounters with Westerners.

Scarcely a month after Sakharov left Moscow, the Hamburg Scientific Forum (part of the Helsinki review process) brought about some sharp exchanges, in which, at one point, the interpreters switched off their headphones and refused to work until the Soviet delegate had cooled down. On the literary front, the Soviet journal that had contracted, sight unseen, to publish Arthur C. Clarke's science-fiction novel 2010, was considerably embarrassed to find that Clarke portrayed Sakharov in his ninetieth year as president of the Soviet Academy of Sciences and a pillar of the Soviet scientific establishment, a prediction that now seems considerably less fantastic than a few weeks ago.
The Soviet authorities will undoubtedly gain from his return. Not only does it reinforce the new, 'liberal' image of the Gorbachev regime, but Sakharov's views on President Reagan's Strategic Defense Initiative (SDI) in many ways coincide with the official Soviet stance. As early as 1983, before the US President announced the programme, Sakharov expressed his doubts on whether such weapons could work. Now, although he admits that such a system could be implemented, he has publicly stated that a "potential enemy with highly developed technology" could always find a means to counter such a space defence - at a considerably lower cost than the SDI system itself.

Soviet disarmament negotiators would have been less happy, however, with Sakharov's comment that it is "ungrounded" to demand that the Americans stop all research on SDI, and that it is "illegal" to demand the halting of such research as a precondition of all other arms-control negotiations. Indeed, "we may infer from general knowledge", he said, that similar research is going on in the Soviet Union, and it would be "simply unrealistic" to stop such research.

In the future, Sakharov says, he will Third-stage managem Ariane, the European space launch vehicle, will not be launched in February 1987 as planned. The European Space Agency (ESA) has postponed the launch of an improved Ariane with a more powerful thirdstage igniter for 6 or 7 weeks while the manufacturer, Arianespace, carries out further tests. Two of the last three launches have failed due to failures of the third stage to ignite. ESA hopes to announce a new launch date later this month.

\section{Supek denies charges $¥ 11$}

Professor Ivan Supek, the Yugoslav physicist and human rights campaigner, is the victim of a virulent campaign in the Yugoslav media. The attacks were triggered by an attempt by the South Slav Academy of Sciences and Arts to obtain for Supek, who retired last year at 70 , a supplementary pension commensurate with his intellectual achievements. But the media, the party organ and the veterans' league SUBNOR claim that such a pension would not be appropriate. Supek, they say, while rector of Zagreb University in 196872, inspired his students with anti-party policies. In a telephone interview with continue to campaign against abuses of human rights, and, in particular, for the liberation of prisoners of conscience. He also hopes to return to scientific work. This latter decision has the approval of the authorities; during the $1970 \mathrm{~s}$, a frequent charge levelled against Sakharov by establishment Soviet scientists was that he had "abandoned science" for human rights, while in 1980 , the decision to exile him to Gor'kii was officially explained as being for his own good, to remove him from distractions such as Western journalists, so that he could continue his scientific career uninterrupted. But an active scientific career implies the right to attend scientific conferences at home and abroad, and Sakharov has already expressed a desire to travel to such conferences, as well as to visit his relatives in the United States. But, only a few months ago, an official spokesperson stated that Sakharov would never be allowed to go abroad, as he has had access to classified information.

It is understandable (although contrary to the International Covenant on Human and Civil Rights) that the Soviet authorities might not want to lose Sakharov's exceptional talents to another country, but Sakharov, it must be stressed, would prefer, all else being equal, to live in Russia. It is "trips with a return" that interest him, not emigration. And he has had no access to classified information since 1968.

Vera Rich

Nature he vehemently denied the charge. It was a time of widespread demands for greater democracy in Yugoslavia, he said but few students were directly concerned, and he himself has always been "very moderate".

erate". dozenen Patca Creationists back in court

THE contention that 'creation science' is religious doctrine dressed in scientific garb is among those facing US Supreme Court justices in the case of Edwards versus Aguillard. At issue is a Louisiana statute requiring evolution and "creation science" to be given "balanced treatment" in schools. The US constitution does not permit laws that can be seen as the "establishment of religion". The Louisiana argument is that the law is entirely secular. Judgement is expected in July, but that is unlikely to be the end of the matter.

Polish fallout corrected

IN the news item "Polish fallout underestimated" Nature 324,$603 ; 1986$ ) the fifth sentence should begin "The emergency network activated on 29 April", and not (as printed) "The emergency on 29 April". 